\title{
Spatial variation of phytoplankton composition, biovolume, and resulting microcystin concentrations in the Nyanza Gulf (Lake Victoria, Kenya)
}

\author{
L. Sitoki $\cdot$ R. Kurmayer $\cdot$ E. Rott
}

Received: 23 June 2011/Revised: 10 January 2012/ Accepted: 26 February 2012/Published online: 14 March 2012

(C) The Author(s) 2012. This article is published with open access at Springerlink.com

\begin{abstract}
The Nyanza Gulf is a large shallow bay of Lake Victoria suffering from eutrophication by human activities. In order to characterize the harmful algal bloom formation as a consequence of eutrophication, both spatially and seasonally, environmental conditions, phytoplankton community composition, and microcystin (MC) concentrations were investigated monthly from Kisumu Bay, and bimonthly from the center of the gulf, as well as quarterly from the Rusinga Channel and the main basin of Lake Victoria between July 2008 and September 2009. The sites located in Kisumu Bay and the central gulf were most strongly affected by eutrophication, including increased nutrient concentrations and phytoplankton growth. More
\end{abstract}

Handling editor: Judit Padisak

Electronic supplementary material The online version of this article (doi:10.1007/s10750-012-1062-8) contains supplementary material, which is available to authorized users.

L. Sitoki

Kenya Marine and Fisheries Research Institute,

P.O. Box 1881, Kisumu, Kenya

L. Sitoki · E. Rott

Institute of Botany, University of Innsbruck,

Sternwartestraße 15, 6020 Innsbruck, Austria

R. Kurmayer $(\square)$

Institute for Limnology, Austrian Academy of Sciences,

Mondseestraße 9, 5310 Mondsee, Austria

e-mail: rainer.kurmayer@oeaw.ac.at than $90 \%$ of the samples obtained from the gulf were dominated by cyanobacteria, whereas diatoms only dominated in the samples obtained from Rusinga Channel and the main lake. In general, Microcystis accounted for the largest part (>50-90\%) of cyanobacterial biovolume. MCs were found in $35(54 \%)$ out of 65 samples and were detected throughout the study period in the gulf, but only in two out of eight samples from the Rusinga Channel and the main lake. A significant linear relationship between Microcystis biovolume and $\mathrm{MC}$ concentration was observed ( $\left.n=65, R^{2}=0.88, P<0.001\right)$. The highest MC concentrations were recorded in Kisumu Bay between November and March $\left(\max .81 \mu \mathrm{g}^{-1}\right.$ ) when Microcystis showed max. biovolume $\left(18 \mathrm{~mm}^{3} \mathrm{l}^{-1}\right.$ in November 2008). The results suggest that seasonal variability did not outweigh the spatial differences in phytoplankton composition and MC production, which is seasonally persistent in Kisumu Bay.

Keywords Harmful algal blooms · Horizontal distribution · Microcystis - Seasonality · Toxicity · Health risk

\section{Introduction}

During the last half century, Lake Victoria has undergone drastic changes in its water quality and biota, which have been attributed to eutrophication and the introduction of exotic species (Hecky, 1993; 
Verschuren et al., 2002). Pollution (nutrient loading) into the lake has increased from both diffuse and pointsources and exerts considerable impact especially on the near-shore areas (Hecky et al., 2010). In addition, fisheries production influenced the trophic status of the lake by the introduction of the piscivorous Nile Perch. The signs of eutrophication were not visible until the 1980s when, for the first time, extensive phytoplankton blooms, massive fish kills, and near-shore belts of water hyacinth Eichhornia crassipes (Mart.) Solms were observed (Ochumba \& Kibaara, 1989; Ochumba, 1990).

Between January and March 2004, the persistence of massive phytoplankton blooms in Kisumu Bay of the Nyanza Gulf resulted in a temporary shutdown of the drinking water supply from the lake. Although the algal blooms were clearly visible, the type of contamination and the underlying causes were not investigated. Scientific evidence of nutrient enrichment in the Nyanza Gulf has been reported by Lung'ayia et al. (2001) and Gikuma-Njuru \& Hecky (2005). Because of a continuously increasing wastewater discharge mostly from the East and South-east sides of the gulf (Calamari et al., 1995), trophic conditions further increased across the gulf (Gikuma-Njuru \& Hecky, 2005). On the other hand, in other gulfs, the concentration of phytoplankton biovolume was found to be relatively low when compared with the observed nutrient concentrations (e.g. Sekadende et al., 2005; Haande et al., 2011). For the Nyanza Gulf, it has been concluded that the high mineral turbidity in the gulf reduces light availability and, therefore, limits algal abundance (Gikuma-Njuru \& Hecky, 2005). In other bays of Lake Victoria, significant dilution effects because of massive water exchange with the main basin have been invoked to explain the relatively low phytoplankton biovolume (Haande et al., 2011). These authors concluded that surface seiches might cause considerable daily water exchange in Murchison Bay (Uganda) and could explain why the increase in total phytoplankton biomass in consequence of nutrient enrichment is not detectable. Similarly, dilution effects from the main basin due to the strong seasonal SE winds were invoked to explain the low phytoplankton abundance in the Mwanza Gulf (Tanzania), although near-shore nutrient enrichment was clearly visible (Sekadende et al., 2005). Consequently, the sensitivity of near-shore areas to eutrophication also depends on the connectivity to the main basin, which is variable both on a spatial and a seasonal scale. It is well known that wind directions are subject to seasonal change, i.e., generally dominant east to south-east during the dry season but west or northwest during the wet season. In the main basin of Lake Victoria, during the dry period (June to September and December to February), the water column increases in stability causing a reduced daily vertical mixing (Hecky, 1993). These physical changes have a significant effect on phytoplankton community composition, i.e., favoring the occurrence of buoyant cyanobacteria (Kling et al., 2001).

The Nyanza Gulf is situated on the NE corner of Lake Victoria close to the equator and is one of the largest bays of L. Victoria $\left(1,400 \mathrm{~km}^{2}\right.$, mean depth $7 \mathrm{~m}$, max. depth $30 \mathrm{~m}$ ). The gulf has an irregular shoreline extending with its longest axis from SW to NE (Fig. 1), showing a pronounced spatial variation in the concentration of macronutrients, such as soluble reactive phosphorus (SRP), nitrate $\left(\mathrm{NO}_{3}-\mathrm{N}\right)$, and soluble reactive silica (SRSi) (Gikuma-Njuru \& Hecky, 2005). Recently, hydrodynamic modeling revealed high horizontal dispersion rates and a strong connectivity with the main basin in the western part of the Nyanza Gulf (Okely et al., 2010). In contrast, in the eastern part of the gulf, the horizontal dispersion rates were much lower, and satellite images revealed significant sediment loading from inflow waters. Consequently, the high turbidity may actually prevent further phytoplankton growth in the eastern part of the Gulf, even under further increased nutrient enrichment conditions.

The aim of the study was to investigate the spatial and seasonal variabilities of eutrophication in the Nyanza Gulf both with regard to nutrient enrichment, phytoplankton composition, and the concentration of the hepatotoxin microcystin (MC). The typical climate at the Nyanza Gulf is characterized by two wet seasons, i.e., from March to May and October to December. However, in the year of this study (in 2008), the period July-September was exceptionally wet. While the spatial-temporal variability of the phytoplankton composition has been studied previously (Gikuma-Njuru \& Hecky, 2005), the concentration of MC has never been recorded in a systematic manner. Several genera of cyanobacteria commonly occurring in Lake Victoria (Anabaena, Microcystis) have the potential to produce MC, which are the most widespread cyanotoxins with over 80 structural 
Fig. 1 Map of Lake Victoria, Kenya sector, showing Nyanza Gulf and the locations of the five sampling stations (NG1, NG2, NG3, NG4, KO5)

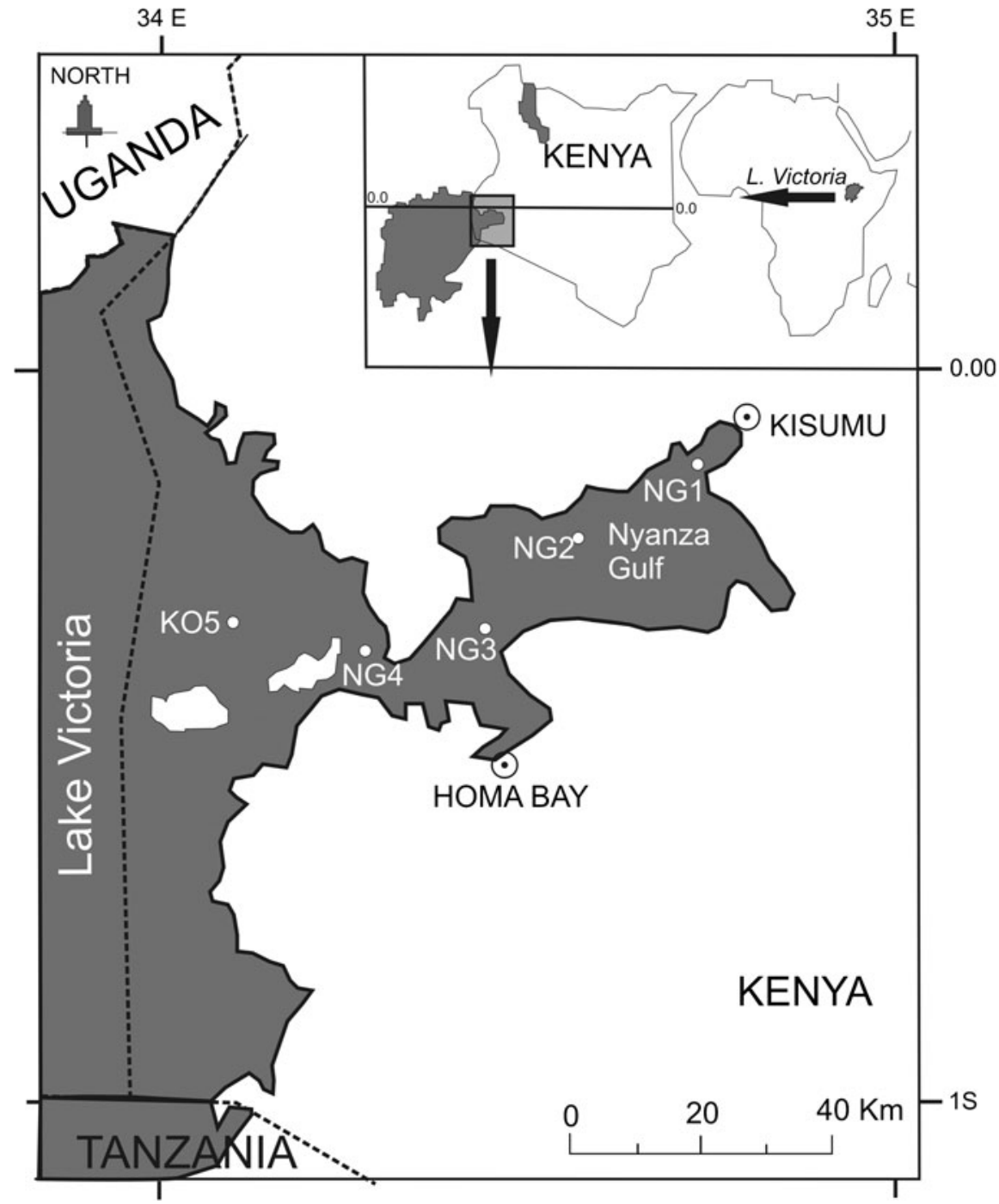

variants (Welker \& von Döhren, 2006). Krienitz et al. (2002) reported MC production from surface water in Kisumu Bay, which was probably the first report on cyanotoxin occurrence from Lake Victoria. In the meantime, MC has been reported from the Mwanza Gulf, Tanzania (Sekadende et al., 2005), and several times from Uganda (Haande et al., 2007; Okello et al., 2010a, b; Semyalo et al., 2010). In the study of Krienitz et al. (2002), MC concentrations $\left(<1 \mu \mathrm{g}^{-1}\right)$ were reported during an Anabaena bloom (Anabaena spp. $>90 \%$ of the phytoplankton biovolume with $8 \times 10^{5}$ cells $\mathrm{ml}^{-1}$ ). The same authors stated that it was unclear as to whether the MCs that were detected could be attributed to all the cyanobacterial species found and the identification of the responsible MCproducing species requires clarification. In contrast, the results from several Ugandan waters including Lake Victoria showed that Microcystis was the only MC producer (Okello et al., 2010a, b). At the current state, it is necessary to clarify as to which cyanobacterial taxa are responsible for MC production in the Nyanza Gulf and which areas of the Nyanza Gulf are most severely affected. We assume that this information is valuable to guide a more safe water use not only for the water supply to the citizens of the town of Kisumu (1 million inhabitants) but also for the population in the neighborhoods that use the lake water directly. 


\section{Materials and methods}

Study area and sampling

Between July 2008 and September 2009, site NG1 (max. depth $3.5 \mathrm{~m}$ ), which was located most closely to Kisumu, was sampled monthly (Fig. 1). The other sites, located in the center of the gulf (NG2, 3), were sampled bimonthly, whereas the station in the Rusinga Channel (NG4) and in the main basin of Lake Victoria (KO5) were sampled quarterly. The maximum depths were 5, 10, 33, and $45 \mathrm{~m}$ at NG2, NG3, NG4, and KO5, respectively. In situ measurements of water temperature and conductivity were made with a submersible Conductivity-Temperature-Depth profiling system (CTD, Sea-bird Electronics $^{\circledR}$, Sea Cat SBE 19). These variables were recorded every $2 \mathrm{~s}$ when lowering the CTD from approximately $0.4 \mathrm{~m}$ (subsurface) to $0.4 \mathrm{~m}$ above the sediment. For each parameter, an average from the upper $10 \mathrm{~m}$ was calculated. Transparency was measured with a Secchi disk $(\varnothing=20 \mathrm{~cm})$ painted black and white by taking the average of the depth at the disappearance and that of the reappearance of the disk in water.

Water samples were collected using a 3-1 horizontal van Dorn sampler. A depth integrated sample was obtained by mixing the samples taken from every meter through the water column at stations NG1-NG3. At NG4 and KO5, only the upper $10 \mathrm{~m}$ of the water column were depth integrated. For phytoplankton analysis, an aliquot of the mixed water sample was fixed with Lugol's solution. For nutrient analysis, pre-rinsed polyethylene bottles were filled with depth integrated samples and kept in an icebox for later analysis (usually within 24-72 h). In order to preserve the samples for later analysis, a few drops of $1 \mathrm{M} \mathrm{HCl}$ were added to induce $\mathrm{pH} 2$ (Eaton et al., 2005). Although water samples from NG1 typically were processed and analyzed within $12 \mathrm{~h}$ (without adding $\mathrm{HCl}$ ), the acidification of the samples from other sites with $\mathrm{HCl}$ probably led to the overestimation of the dissolved reactive nutrients, especially SRP. For MC analysis, 50-1,000 $\mathrm{ml}$ were filtered through glass fiber filters (Whatman GFC, Kent, UK) directly in the field using a vacuum pump. The filters were dried immediately in an oven at $45^{\circ} \mathrm{C}$ for $48 \mathrm{~h}$ and stored in the freezer at $-18^{\circ} \mathrm{C}$.
Nutrient analysis

Soluble reactive phosphorous, nitrate nitrogen $\left(\mathrm{NO}_{3}-\right.$ $\mathrm{N}$ ), and ammonia $\left(\mathrm{NH}_{4}-\mathrm{N}\right)$ were determined from the filtrate (Whatman GFC) using the ammonium molybdate method (Wetzel \& Likens, 2000), sodium salicylate method (Müller \& Wiedemann, 1955) and the indophenol blue method (Krom, 1982), respectively. Total phosphorus (TP) and total nitrogen (TN) were determined as SRP and $\mathrm{NO}_{2}-\mathrm{N}$, respectively, from the unfiltered water sample subsequent to persulfate digestion (determination of $\mathrm{NO}_{2}-\mathrm{N}$ was made after passing the sample through a cadmium reduction column). Soluble reactive silica $\left(\mathrm{SiO}_{2}\right)$ was determined as yellow molybdate-silicic acid (Wetzel \& Likens, 2000).

\section{Phytoplankton analysis}

Phytoplankton was identified and counted at $400 \times$ using an inverted microscope following the method of Utermöhl (1958). For each taxon, the cell length and width were measured from a minimum of 20 randomly selected specimens. Biovolume was calculated using geometric approximations (Rott, 1981; Wetzel \& Likens, 2000). Microcystis colonies were measured at $40 \times$ magnification. The density of the cells per unit of the projection area of the colony was estimated using a higher magnification $(400 \times)$. The depth of each colony was estimated by focusing on the top and bottom of the colony using the fine adjustment of the microscope. The following taxonomic literature was used for the identification of Cyanobacteria: Komárek \& Anagnostidis (1998), Komárek et al. (2002), Komárek \& Anagnostidis (2005). The eukaryotic algae taxonomic literature included Huber-Pestalozzi (1942) and Krammer \& Lange-Bertalot (1988, 1991) for diatoms, Komárek \& Fott (1983) for Chlorococcales and Huber-Pestalozzi (1950) for Cryptophyta and Dinophyta, and Talling (1987) for Zygnematophyceae. A detailed description of all phytoplankton species can be found in Sitoki (2010). Species diversity was expressed by means of the ShannonWiener diversity index $(H)$.

\section{Microcystin analysis}

Two sets of samples were analyzed: Microcystis strains and field samples. Sixteen strains of the genus 
Microcystis were isolated from NG1 and NG3 by streaking on an agar plate as described (Rippka, 1988). The strains were grown in the BG11 medium in a Heraeus culture chamber $\left(25^{\circ} \mathrm{C}, 40 \mu \mathrm{mol} \mathrm{m}{ }^{-2} \mathrm{~s}^{-1}\right.$, 16:8 h light-dark cycle). Strains were harvested by filtering in the same way as the field samples. For the extraction of MCs from filters, $75 \%$ (w/v) methanol was used as described (Fastner et al., 1999). MC analysis was performed using HPLC-DAD with acetonitrile ( $0.05 \%$ trifluoroacetic acid) and Millipore water as solvents on a LiChrospher ${ }^{\circledR} 100 \mathrm{RP}-18 \mathrm{e}$ $(5 \mu \mathrm{m})$, LiChroCART $^{\circledR} 250-4$ cartridge system using an HP 1100 ChemStation (Lawton et al., 1994, Kurmayer et al., 2003). MCs were identified by their retention time and characteristic UV absorption spectra. MCs were quantified at $240 \mathrm{~nm}$, and the concentrations of all the MC variants were determined as MC-LR equivalents from the regression equation obtained using [D-MeAsp, D-Mdha]-MC-LR (Cyanobiotech $\mathrm{GmbH}$, Berlin, Germany). HPLC fractions identified as MC were collected manually and analyzed by matrix-assisted laser desorption/ionization time-of-flight mass spectrometry (MALDI-TOF MS), (PerSeptive BioSystems, Framingham MS, USA) as described by Erhard et al. (1997). MCs are reported in volumetric units $\left(\mu \mathrm{g} \mathrm{l}^{-1}\right)$ and in cellular content (fg cell $^{-1}$ or $\mu \mathrm{g} \mathrm{mm}^{-3}$ of Microcystis).

Statistical analysis

In order to determine the dependence of phytoplankton species abundance on the environmental parameters across sampling stations NG1-KO5, Canonical Correspondence Analysis (CCA) was performed. However, it was not possible to relate any of the environmental variables (Tables 1,2 ) to the phytoplankton community composition by CCA with statistical significance. Multiple linear regression analysis was used to test the relationship between the Microcystis spp. biovolume and proportion and the influence of the nine environmental variables as used for CCA. A forward stepwise analysis was performed to select the independent variable for inclusion, which makes the most significant unique (or additional) contribution to the prediction of the data. The data were $\log$ transformed to fulfill the assumptions of normality and constant variance. The Durbin-Watson statistic was 2.4 (Microcystis biovolume) versus 1.8 (Microcystis proportion), implying that the residues of the regression were not related. The $F$ value to enter the respective model was set as the default $(P<0.05)$ using SPSS 15.0 for Windows (SPSS GmbH Software, Munich, Germany).

\section{Results}

Environmental conditions and phytoplankton composition in Kisumu Bay (NG1)

Throughout the study period, the temperature showed minor seasonal variations with the maxima observed during the wet seasons (Table 1). Water transparency was low and showed little seasonal variation (mean $\pm \mathrm{SD}, 0.2 \pm 0.03 \mathrm{~m}$ ). Overall SRP concentrations were high $\left(74 \pm 37 \mu \mathrm{g} \mathrm{l}^{-1}\right)$ and showed temporal variability with minima in October 2008 and July 2009. Nitrate $\left(\mathrm{NO}_{3}-\mathrm{N}\right)$ concentrations varied 60 -fold between October 2008 (309 $\mu \mathrm{g}^{-1}$, start of the wet season) and December $2008\left(5 \mu \mathrm{g} \mathrm{l}^{-1}\right.$, end of the wet season). The concentrations of $\mathrm{NH}_{4}-\mathrm{N}$ were generally higher than those of $\mathrm{NO}_{3}-\mathrm{N}$ with the minima occurring (52-99 $\mu \mathrm{g} \mathrm{l}^{-1}$ ) from January to May 2009 and the maxima from August to September 2008 (>200 $\mu \mathrm{g}$ $\left.1^{-1}\right)$. Reductions in TN concentrations were recorded from December to February, coinciding with the mats formed by the water hyacinth.

Phytoplankton biovolume showed its maxima during the wet seasons (Nov-Dec 2008 and May 2009) and in September 2009 at the end of the dry season (Fig. 2). Cyanobacteria were the most dominant, contributing $>50 \%$ to the total phytoplankton biovolume. Except for one seasonal maximum of Anabaena spp. (36\%) in September 2009, Microcystis spp. constituted the major part $(78 \pm 16 \%)$ of the cyanobacteria. Within Microcystis spp. four species were observed according to morphological characters: $M$. botrys Teiling, M. wesenbergii Komárek, and the tropical species $M$. panniformis Komárek and $M$. protocystis Crow. Komárek et al. (2002) distinguished the two species from $M$. aeruginosa based on colony morphology and life cycle. M. panniformis formed spheroidal colonies with several adjacent parts appearing like large intestines. Macroscopic colonies of this species were cloudy, irregular, lobate, and disintegrated (cells were $4.5 \pm 0.7 \mu \mathrm{m}$ in diameter and $38 \pm 9 \mu^{3}$ in biovolume). M. protocystis differed from $M$. aeruginosa because of its obligatory sparse 


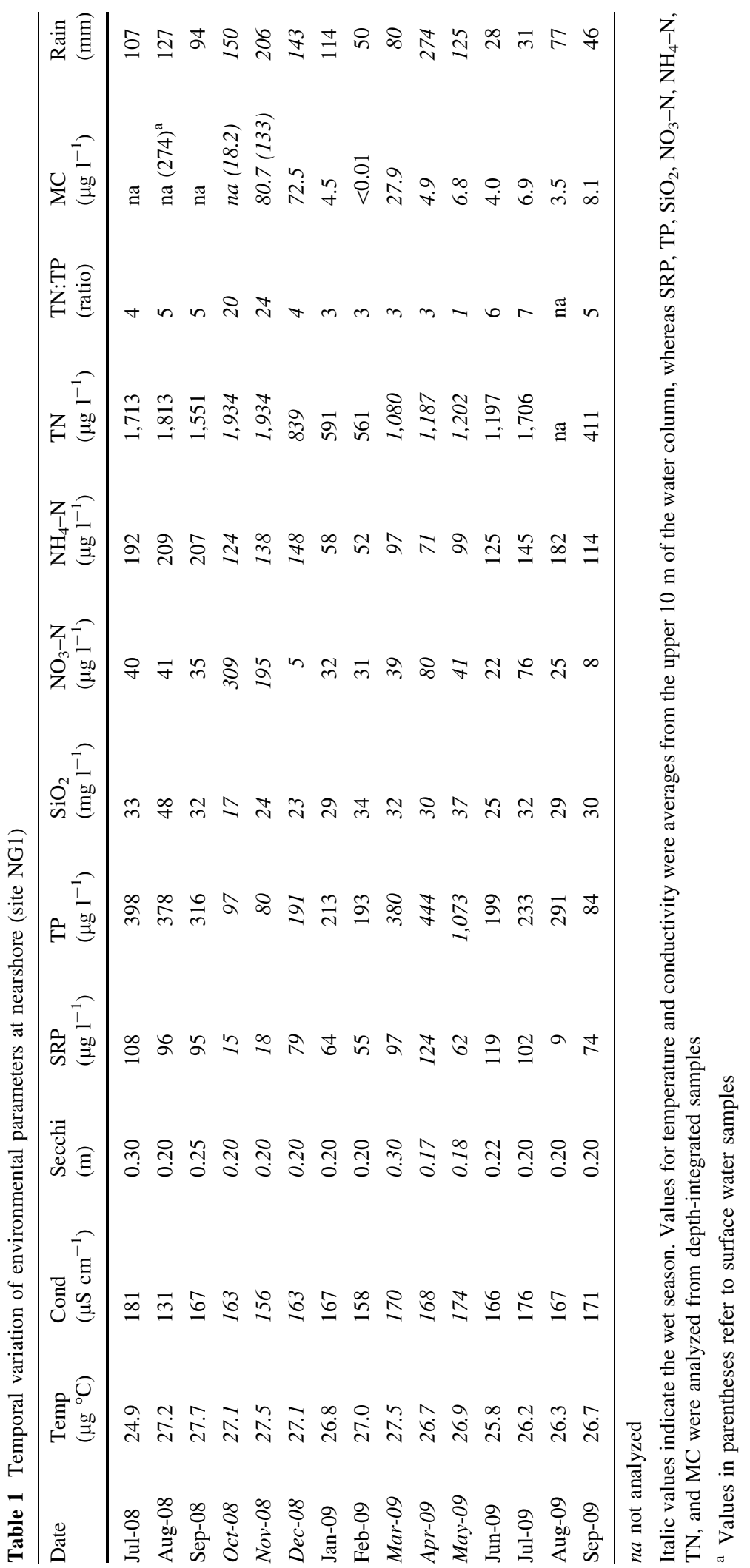




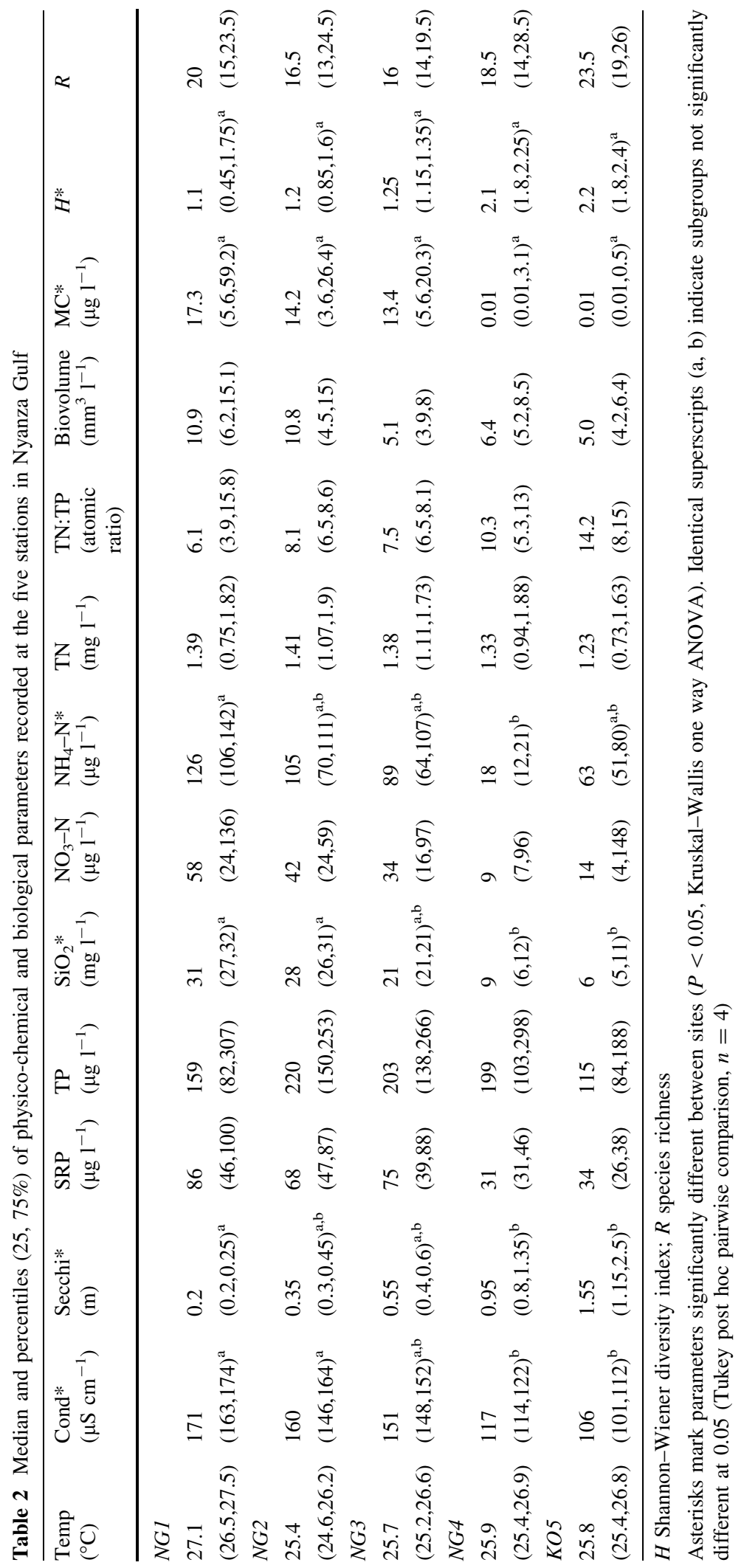


Fig. 2 Absolute phytoplankton biovolume composition $\left(\mathrm{mm}^{3} \mathrm{l}^{-1}\right)$ assigned to phytoplankton classes or families (A) and phytoplankton genera (B) as recorded monthly from 2008 to 2009 at sampling station NG1. For the sake of clarity, only genera contributing $>5 \%$ to total phytoplankton biovolume are shown. For species composition, see Supplement Table 1. Top bar indicates the periods of dry and wet seasons

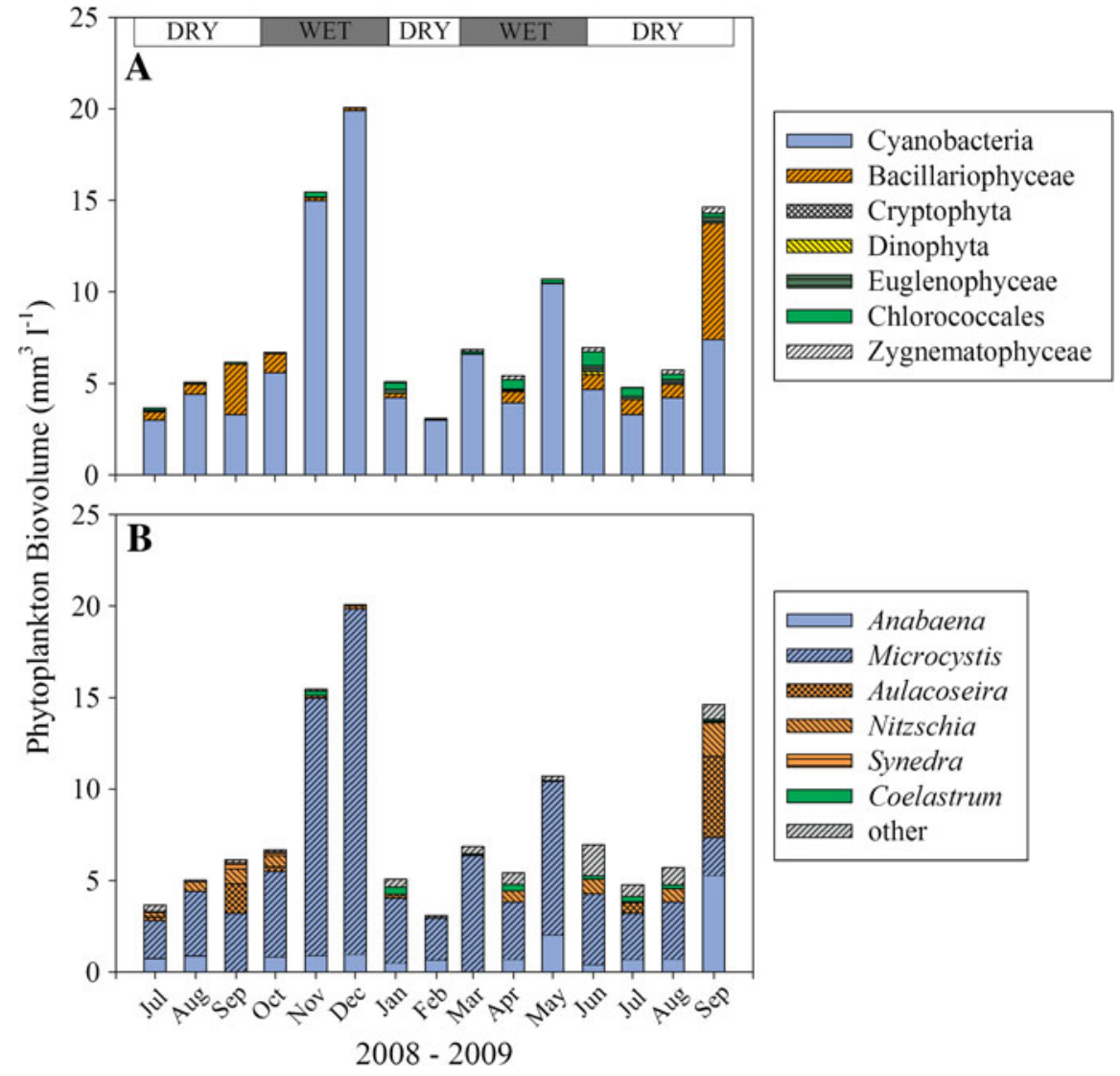

arrangement of cells in colonies, a characteristic that is observed in $M$. aeruginosa only in samples from benthic environments (Komárek et al., 2002). In addition, the species specific formation of special mucilaginous envelopes in individual cells (pseudovacuoles) of $M$. protocystis was observed. The colonies of $M$. protocystis were irregular, flat, and sometimes appear hollow (cells were $4.4 \pm 0.7 \mu \mathrm{m}$ in diameter and $40 \pm 7 \mu \mathrm{m}^{3}$ in biovolume). For subsequent calculations, all morphospecies were combined under Microcystis spp. Diatoms were abundant during the dry seasons in 2008 and 2009, and peaked in September. The seasonal succession of dominant diatom species was similar in both years: Nitzschia spp. occurred most frequently early in the dry season (June-July), whereas Aulacoseira sp. was the most abundant in the late dry season (September). From January to September 2009, there was a gradual increase in the abundance and diversity of Chlorococcales and Zygnematophyceae. Species diversity was significantly higher in the dry season $(H=1.79)$ than in the wet season $(H=0.88)$ in 2009 ( $t$ test, $n=3, P<0.05$ ).
Environmental conditions and phytoplankton composition along the Nyanza Gulf (NG1-KO5)

Dissolved nutrient fractions of $\mathrm{P}, \mathrm{N}$, and $\mathrm{Si}$ (SRP, $\mathrm{NH}_{4}-\mathrm{N}$, and $\mathrm{SiO}_{2}$ ) as well as conductivity decreased from inshore to offshore (Table 2). In contrast, the Secchi depth significantly increased from NG1 (Kisumu Bay) to NG4 (Rusinga Channel) and to the main lake (KO5). In total, 101 phytoplankton species were identified and the phytoplankton composition showed striking differences along the transect. Cyanobacteria were the dominant group in 11 out of 12 samples from NG1 to NG3 and Microcystis spp. constituted $>50 \%$ of the total algal biovolume (Fig. 3). Anabaena spp. was the most abundant at NG4 and KO5, i.e., contributed 46 and $40 \%$ at NG4 and KO5, respectively, each in November 2008. In contrast to the cyanobacteria, the diatoms increased in proportion from NG1 to NG3 to NG4 and KO5 and primarily comprised Aulacoseira spp., Nitzschia spp., Synedra cunningtonii G.S. West, and Urosolenia victoriae (Schröder) Rott \& Kling. The Rusinga Channel and the 
Fig. 3 Absolute phytoplankton biovolume composition $\left(\mathrm{mm}^{3} \mathrm{l}^{-1}\right)$ assigned to phytoplankton classes or families (A) and phytoplankton genera (B) as recorded at four dates in 2008 (Nov) and in 2009 (Mar, Jul, and Sept.) for each sampling station (NG1, NG2, NG3, NG4, and KO5). For the sake of clarity, only genera contributing $>5 \%$ to total phytoplankton biovolume are shown. For species composition, see Supplement Table 1

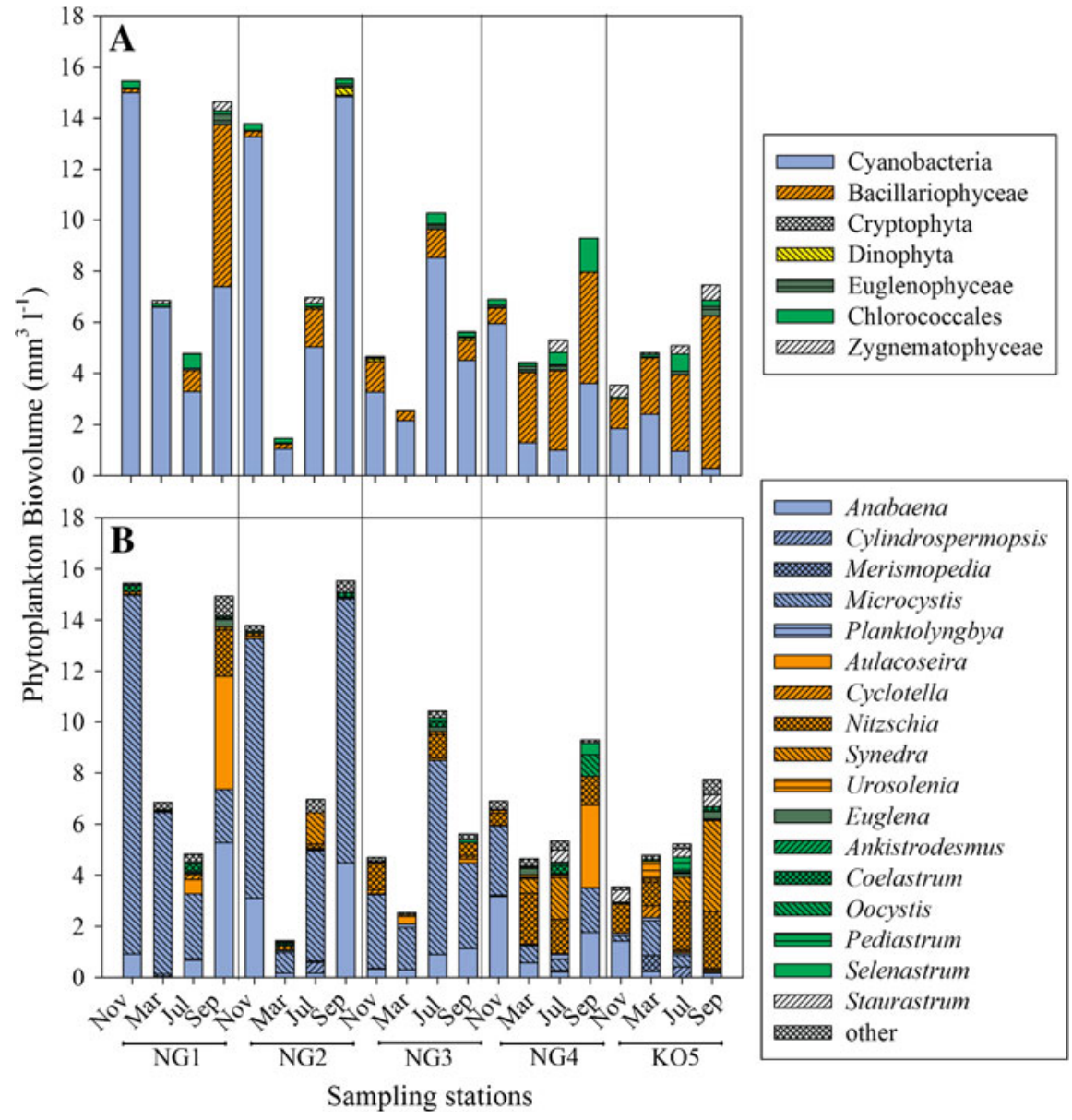

Table 3 Frequency of occurrence (\%) of MC variants and proportion in total MC (mean \pm SE) as recorded from field samples $(n=35)$ and Microcystis strains $(n=12)$

\begin{tabular}{|c|c|c|c|c|c|c|c|}
\hline \multirow[t]{2}{*}{ MC variant } & \multirow[t]{2}{*}{$\mathrm{M}+\mathrm{H}^{+}$} & \multirow[t]{2}{*}{ Structural variant } & \multirow[t]{2}{*}{ Retention (min) } & \multicolumn{2}{|c|}{ Frequency } & \multicolumn{2}{|l|}{ Proportion } \\
\hline & & & & Field & Strains & Field & Strains \\
\hline $\mathrm{MC1}$ & 1,024 & [Asp3] MC-RR & $14.1-14.2$ & 11 & 0 & $5.4 \pm 4$ & 0 \\
\hline MC2 & 1,038 & MC-RR & 15.4 & 0 & 8 & 0 & $0.8 \pm 0.8$ \\
\hline MC3 & 1,063 & [NMeSer7] MC-YR ${ }^{\mathrm{a}}$ & $16.6-17.0$ & 8 & 58 & $6.3 \pm 3.8$ & $5.2 \pm 1.6$ \\
\hline MC4 & 1,031 & [Asp3] MC-YR & $17.9-18.0$ & 0 & 58 & $0.3 \pm 0.3$ & $32 \pm 8.2$ \\
\hline MC5 & 1,045 & MC-YR & $18.5-18.8$ & 62 & 58 & $31 \pm 52$ & $17 \pm 4.6$ \\
\hline \multirow[t]{2}{*}{ MC6 } & 995 & MC-LR & 19.9-20.1 & 89 & 92 & $50 \pm 6$ & $32 \pm 7$ \\
\hline & & Unknown & $22.1-25.8$ & 46 & 50 & $6.8 \pm 3$ & $14 \pm 9$ \\
\hline
\end{tabular}

${ }^{a}$ Described by Okello et al. (2010b)

main lake had significantly higher species diversity and evenness when compared with the inner gulf sites (Table 2). Algal biovolume showed its maxima at NG1 and NG2 and its minima at NG4 and KO5. The total phytoplankton biovolume was significantly correlated to the abundance of Microcystis spp. ( $\left.n=20, R^{2}=0.70, P<0.008\right)$. It is concluded that seasonal variation did not outweigh the spatial difference in phytoplankton composition along the transect. 
Microcystin concentrations

Altogether, 65 field samples were analyzed, of which 35 samples were found to be MC positive (54\%). In general, MCs were detected when Microcystis was dominant. The proportion of MC positive samples increased significantly when more than $10^{6}$ Microcystis cells were extracted and analyzed for MC $(=35$ (73\%) out of 48 samples). Six different variants of MCs could be undoubtedly identified (Table 3). MCLR (M + H 995) and MC-YR (M + H 1045) were the most abundant variants comprising on average $50 \pm 6$ and $31 \pm 5 \%$ of the total MC concentration, each. Unknown MC variants comprised $6.8 \pm 3 \%$ of the total MC concentration. In total, 16 strains assigned to M. panniformis were isolated, and 12 strains $(75 \%)$ were found to contain MC. In general, there was a close match between the proportion of MC structural variants recorded from the field samples and from the cultured Microcystis strains (Table 3). Nevertheless, within the strains, a large variation in the cellular MC content was observed (mean $\pm \mathrm{SE}, 232 \pm 49 \mathrm{fg}$ cell $^{-1}$ or $5.8 \pm 1.2 \mu \mathrm{g} \mathrm{mm}^{-3}$ of biovolume, range $17-553 \mathrm{fg}$ cell $^{-1}$ or $0.4-13.8 \mu \mathrm{g} \mathrm{mm}^{-3}$ of biovolume).

During Microcystis bloom formation, the highest MC concentrations were recorded, i.e., from surface scums occurring at NG1 in August and October 2008 MC concentrations of 274 and $133 \mu \mathrm{g} \mathrm{l}^{-1}$, respectively. MC concentrations gradually decreased from NG1 (Kisumu Bay) to NG2, NG3, and significantly lowest concentrations were recorded in Rusinga Channel (NG4) and KO5 (Table 2). At inshore (NG1), MCs were detected almost year-round with a maximum during the wet season (Table 1). Taking all the data together, the MC concentration was significantly correlated with Microcystis cell number: $y=0.0004 x-5.0487$, or Microcystis biovolume: $y=10.498 x-5.0487 \quad\left(n=65, \quad R^{2}=0.88, \quad P<\right.$ $0.001)$, where $y$ is the MC concentration $\left(\mu \mathrm{g}^{-1}\right)$ and $x$ is the Microcystis cell number (cells $\mathrm{ml}^{-1}$ ) or biovolume $\left(\mathrm{mm}^{3} \mathrm{l}^{-1}\right)$. In contrast, there was no correlation between the $\mathrm{MC}$ concentrations and the Anabaena cell number $\left(n=65, \quad R^{2}=0.05\right.$, $P=0.98)$. Using multiple regression analysis, only the variable conductivity was included in the forward stepwise method, explaining the Microcystis biovolume: $y=-11.501+5.502 x$ (adjusted $R^{2}=$ $0.47, n=20, P<0.001$ ) or Microcystis proportion: $y=-9.451+5.104 x$ (adjusted $R^{2}=0.54$ ), where $y$ is the $\log _{10}$ Microcystis biovolume $\left(\mathrm{mm}^{3} \mathrm{l}^{-1}\right)$ or proportion and $x$ the $\log _{10}$ conductivity $(\mu \mathrm{S})$. It is concluded that the conductivity, which is reflecting at least partly nutrient input from the terrestrial runoff, can significantly predict Microcystis abundance that is further linearly related with the MC concentration.

\section{Discussion}

Nutrient enrichment in the Nyanza Gulf

The Nyanza Gulf is a semi-closed bay with a limited water exchange with the main basin (Calamari et al., 1995). The isolated situation distinguishes the Nyanza Gulf from the numerous more open bays where the impacts of eutrophication are probably diminished by dilution effects resulting from surface seiches (Haande et al., 2011). Spatial differences in conductivity along the main axis from the shallow areas of the Nyanza Gulf (NG1-3, Table 2) to the deeper sites of the central lake basin (NG4 and KO5) were reported previously (Gikuma-Njuru \& Hecky, 2005; Hecky et al., 2010) and were confirmed in this study. As mentioned in those earlier studies, the evidence for eutrophication in the Nyanza Gulf comprises (1) a significant reduction in transparency, (2) shifts in phytoplankton composition from diatoms to cyanobacteria, and (3) increased macronutrient concentrations. In 2008, Gikuma-Njuru reported that the average $\mathrm{TP}$ concentration almost doubled from $68 \mathrm{\mu g}^{-1}$ (2000-2002, Gikuma-Njuru $\&$ Hecky, 2005) to $107 \mu \mathrm{g} \mathrm{l^{-1 }}$ (2005-2006). During this study, TP concentration further significantly increased (on average $199 \mu \mathrm{g}^{-1}$, Table 2) suggesting that severe eutrophication occurred within a period of less than 10 years. However, the increase in TP is not matched with a similar increase in $\mathrm{TN}$, which has changed from an average of $983 \mu \mathrm{g} \mathrm{l}^{-1}$ in 2000-2002 (Gikuma-Njuru \& Hecky, 2005) to $1,356 \mu \mathrm{g} \mathrm{l^{-1 }}$ in the present study. A large portion of this nutrient increase can be attributed to the allochthonous fluvial nutrient inputs from agricultural and urban areas in the catchment (Gikuma-Njuru, 2008; Hecky et al., 2010). The rapid increase in nutrient concentrations seems to be further enhanced by heavy rainfall (Hecky et al., 2010). Based on the average TP concentrations, the trophic classification system for tropical lakes (Salas \& Martino, 1991) assigns the Nyanza Gulf to a 
hypereutrophic state. On the other hand the dissolved inorganic nitrogen (DIN) mainly $\mathrm{NO}_{3}-\mathrm{N}$ concentration is relatively low when compared with TN. This discrepancy between DIN and TN seems to be a common feature of many tropical water bodies. For example, in Lake Maracaibo, Venezuela nitrogen availability was found to be regulated by efficient diurnal nutrient (nitrogen) recycling based largely on dissolved organic nitrogen in spite of low DIN (Gardner et al., 1998).

Functional groups of phytoplankton in the Nyanza Gulf

In accordance with the functional classification system (Reynolds, 2006), the following functional groups were recognized: (i) Group M, as represented by Microcystis spp. inhabiting shallow, daily mixed layers in eutrophic lakes. It is well known that this species tolerates high insolation but is sensitive to flushing and low total light availability (Paerl et al., 1983). This group $M$ formed surface blooms (NG1NG3) most of the year (Fig. 3); (ii) Group H, as represented by nitrogen-fixing Anabaena spp. was observed in high abundance only at NG4 (46\%) and KO5 (40\%) in November 2008, and at NG1 (36\%) in September 2009. This group is believed to tolerate low DIN availability but is considered sensitive to mixing and poor light conditions; (iii) Groups C, P as represented by large centric diatoms (Aulacoseira spp.) that increased in abundance at NG1 and NG4 during the dry season (peak in September 2009); and (iv) Group N, thin and long diatoms (e.g., Nitzschia spp. and Synedra cunningtonii) found in highest abundances at KO5 at the end of the dry season (September 2009).

Cyanobacteria were dominant at the three sites within the gulf reaching from Kisumu to station NG3 covering a distance of $40 \mathrm{~km}$, which corresponds to $>50 \%$ of the total area of the shallower sector of the Nyanza Gulf. The persistent dominance of cyanobacteria was almost exclusively due to Microcystis spp. contributing $>70 \%$ of cyanobacterial biovolume. According to Komárek et al. (2002) the dominating Microcystis morphospecies were classified into $M$. panniformis and $M$. protocystis rather than into M. aeruginosa (Kützing) Kützing and M. flos-aquae (Wittrok) Kirchner. In contrast, the occurrences of M. aeruginosa and M. flos-aquae in Nyanza Gulf have been reported previously (e.g., Lung'ayia et al., 2000). In earlier studies on L. Victoria, the morphospecies of Microcystis spp. were either assigned to M. aeruginosa (Kützing) Kützing (Haande et al., 2007) or M. wesenbergii and M. aeruginosa (Haande et al., 2011), or were not differentiated (e.g., Okello et al., 2010a, b). We cannot fully exclude the occurrence of $M$. aeruginosa, however, it is likely that it was not dominant during the period of this study. Since the morphospecies of $M$. panniformis and M. protocystis have been described relatively recently (Komárek et al., 2002) it is possible that colonies of $M$. panniformis have been described as $M$. aeruginosa earlier. Alternatively, it has been shown that morphological variation of Microcystis spp. can occur seasonally within the same waterbody which could be because of changes in Microcystis spp. genetic composition (e.g., Harada et al., 2001; White et al., 2003; Ozawa et al., 2005). The absolute dominance of Microcystis spp. is in striking contrast to the more diverse phytoplankton species composition in Murchison Bay in Uganda where besides Microcystis spp. (usually $<30 \%$ of cyanobacteria biovolume) several other genera comprised significant portions of the cyanobacterial biovolume, i.e., Anabaena spp. (10\%), Aphanocapsa spp. (20\%), Planktolyngbya circumcreta G.S. West (10\%), Gomphosphaeria aponina Kuetzing (10\%), and Merismopedia spp. (15\%), (Okello et al., 2010a; Haande et al., 2011).

In an environment with high phosphorus availability, nitrogen limitation can play a significant role in selecting dominant taxa (Reynolds, 2006). Nitrogen limitation has been considered the principal factor leading to the proliferation and dominance of heterocystous cyanobacteria in large parts of Lake Victoria (Kling et al., 2001) and in the Nyanza Gulf (GikumaNjuru \& Hecky, 2005). The TN:TP ratio observed in the Nyanza Gulf corresponds closely to recent findings from highly eutrophic Ugandan shores (range 7-15 atomic ratio, Haande et al., 2011). In Kisumu Bay, neither the low TN:TP ratio nor the low DIN:SRP ratio can explain the dominance of the non-nitrogen fixing Microcystis. Here, and in other parts of the gulf (the deep locations of NG4 and KO5), it is possible that physical factors, such as the relationship of the euphotic zone to the mixing depth and/or variations in turbidity (organic and mineral seston) rather than TN:TP ratios, regulate phytoplankton composition. Indeed, it is likely that under turbid and polymictic 
conditions Microcystis has an advantage over Anabaena in shallow waters even under N-limiting conditions. When compared with Anabaena, Microcystis forms larger colonies (colonies of Microcystis $>1 \mathrm{~mm}$ in diameter were observed). Because of buoyancy, the larger colonies can rise to the surface more quickly, and Microcystis would benefit from the increased light availability to a larger extent than Anabaena. In the shallow part of the gulf, mixing allows for sufficient light availability to sustain the growth of Microcystis over the extended periods even when the depth of the euphotic zone is much lower than the mixing depth $\left(Z_{\text {eu }} \ll Z_{\text {mix }}\right)$. In contrast, the dominance of the nitrogen-fixing Anabaena is not favored by continuous mixing but requires temporarily stratified conditions, as observed offshore (GikumaNjuru \& Hecky, 2005). The increasing dominance of diatoms in the Rusinga Channel and in the main lake station seems to be facilitated by a reduced turbidity resulting in the higher transparency of the water column.

\section{Microcystin concentration in the Nyanza Gulf}

Coinciding with eutrophication, a regular MC occurrence was observed. MC concentrations recorded in Kisumu Bay and NG2, NG3 were among the highest from Lake Victoria that had ever been reported (Sekadende et al., 2005; Okello et al., 2010a, b; Haande et al., 2011). The highest MC concentrations were recorded between November and March coinciding with the wet season when rainfall and nutrient enrichment from the catchment increased. From the highly significant relationship between Microcystis and MC concentrations, it must be concluded that Microcystis is the major MC producer while the contribution of Anabaena is of minor importance. This conclusion corresponds to recent results on cyanobacterial blooms in Uganda (Okello et al., 2010a, b). Genetic studies (Okello et al., 2010a) demonstrated that, in samples from Uganda, the genotypes encoding MC synthesis assigned to Microcystis consistently occurred, while those assigned to Anabaena were never detected.

Consequently, Microcystis blooms persisting in large parts of the Nyanza Gulf may result in a risk of MC contamination of drinking water and of the food chain. An intoxication incident in Caruaru, Brazil in
1996 involving blooms of $M$. panniformis and $M$. protocystis resulted in fatalities of several dialysis patients (Komárek et al., 2001). A recent survey on the MC exposure risk from Ugandan lakes revealed that $>50 \%$ of the WHO lifetime tolerable daily intake (TDI) guideline stems from the consumption of (untreated) drinking water (Poste et al., 2011). According to Reynolds (2006), even higher phytoplankton biomass (biovolume $>10 \mathrm{~mm}^{3} \mathrm{l}^{-1}$ ) could be predicted from the presently observed nutrient concentrations in the Nyanza Gulf in the near future. Strategies of dealing with MCs from lake water used for the drinking water supply should involve a regular monitoring of the cell numbers of toxigenic cyanobacteria in the raw water. When Microcystis cells pass a certain threshold $\left(>2 \times 10^{3}\right.$ cells $\mathrm{ml}^{-1}$, Chorus \& Bartram, 1999), additional treatment steps would be necessary, including flocculation and ozonation to remove the particles, followed by sand filtration or activated carbon filtration for removing dissolved MCs and other toxic compounds. Particularly sand filtration has been shown to be efficient in removing MCs from raw water (Chorus \& Bartram, 1999). Nevertheless, raising public awareness through the media has to be fostered. Since, during dry periods, alternative water sources are scarce, the installation of in-situ/household biosand filtration units (Cronberg \& Annadotter, 2006) that can be used for water purification should be considered.

Acknowledgments The authors would like to express their gratitude to Jared Babu, Ephraim Odada, and the mercantile staff for their excellent assistance in the field and laboratory. The authors would also like to thank the staff of the Limnology Institute in Mondsee (Josef Knoblechner) for their technical assistance during the MC analysis. The Microcystis species determination was confirmed by Hedy Kling and others at the 18th Symposium of the International Association for Cyanophyte Research (IAC) in České Budějovice. The comments of three anonymous reviewers to an earlier version of this manuscript are greatly acknowledged. This study was funded by the Austrian Agency for International Cooperation in Education and Research (OeAD-GmbH) as part of the NorthSouth Dialogue program with additional support from the International Foundation for Science (IFS) research grant no. A/4716-1 to S.L., the University of Innsbruck, KMFRI, and the Austrian Science Fund (FWF): [P20231].

Open Access This article is distributed under the terms of the Creative Commons Attribution License which permits any use, distribution, and reproduction in any medium, provided the original author(s) and the source are credited. 


\section{References}

Calamari, D., M. O. Akech \& P. B. O. Ochumba, 1995. Pollution of Winam Gulf, Lake Victoria, Kenya: a case study for preliminary risk assessment. Lakes Reservoirs: Research \& Management 1: 89-106.

Chorus, I. \& J. Bartram (eds), 1999. Toxic Cyanobacteria in Water-A Guide to Their Public Health Consequences, Monitoring and Management. WHO, E \& FN Spon, London: p. 416.

Cronberg, G. \& H. Annadotter, 2006. Manual on Aquatic Cyanobacteria. A Photo Guide and Synopsis of Their Toxicology. ISSHA, Copenhagen, ISBN 87-990827-0-5.

Eaton, A. E., Clesceri, L. S., Rice, E. W. \& A. E. Greenberg (eds), 2005. Standard Methods for the Examination of Water \& Wastewater: Centennial Edition. American Public Health Association, American Water Works Association, Water Environment Federation, United Book Press, Inc., Baltimore, MD: 1360 pp.

Erhard, M., H. von Döhren \& P. Jungblut, 1997. Rapid typing and elucidation of new secondary metabolites of intact cyanobacteria using MALDI-TOF mass spectrometry. Nature Biotechnology 15: 906-909.

Fastner, J., M. Erhard, W. W. Carmichael, F. Sun, K. L. Rinehart, H. Rönicke \& I. Chorus, 1999. Characterization and diversity of microcystins in natural blooms and strains of the genera Microcystis and Planktothrix from German freshwaters. Archiv für Hydrobiologie 145: 147-163.

Gardner, W. S., J. F. Cavaletto, H. A. Bootsma, P. J. Lavrentyev \& F. Troncone, 1998. Nitrogen cycling rates and light effects in tropical Lake Maracaibo, Venezuela. Limnology and Oceanography 43: 1814-1825.

Gikuma-Njuru, P., 2008. Physical and biogeochemical gradients and exchange processes in Nyanza Gulf and main Lake Victoria (East Africa). Ph.D. Thesis. University of Waterloo, Ontario, Canada: p. 140.

Gikuma-Njuru, P. \& R. E. Hecky, 2005. Nutrient concentrations in Nyanza Gulf, Lake Victoria, Kenya: light limits algal demand and abundance. Hydrobiologia 534: 131-140.

Haande, S., A. Ballot, T. Rohrlack, J. Fastner, C. Wiedner \& B. Edvardsen, 2007. Diversity of Microcystis aeruginosa isolates (Chroococcales, cyanobacteria) from East-African water bodies. Archives of Microbiology 188: 15-25.

Haande, S., T. Rohrlack, R. P. Semyalo, P. Brettum, B. Edvardsen, A. Lyche-Solheim, K. Sorensen \& P. Larsson, 2011. Phytoplankton dynamics and cyanobacterial dominance in Murchison Bay of Lake Victoria (Uganda) in relation to environmental conditions. Limnologica 41: 20-29.

Harada, K., T. Mayumi, T. Shimada, K. Fujii, F. Kondo, H. Park \& M. F. Watanabe, 2001. Co-production of microcystins and aeruginopeptins by natural cyanobacterial bloom. Environmental Toxicology 16: 298-305.

Hecky, R. E., 1993. The eutrophication of Lake Victoria. Verhandlungen der Internationalen Vereinigung für Theoretische und Angewandte Limnologie 25: 39-48.

Hecky, R. E., R. Mugidde, P. S. Ramlal, M. R. Talbot \& G. W. Kling, 2010. Multiple stressors cause rapid ecosystem change in Lake Victoria. Freshwater Biology 55: 19-42.
Huber-Pestalozzi, G., 1942. Das Phytoplankton des Süsswassers, 2. Teil (2. Hälfte) pp. I-X + 367-549. Schweizerbart'sche Verlagsbuchhandlung, Stuttgart.

Huber-Pestalozzi, G., 1950. Cryptophyceen, Chloromonadinen, Peridineen. Das Phytoplankton des Süsswassers, 3. Teil pp. I-LXIX + 1-310. Schweizerbart'sche Verlagsbuchhandlung, Stuttgart.

Kling, H. J., R. Mugidde \& R. E. Hecky, 2001. Recent changes in the phytoplankton community of Lake Victoria in response to eutrophication. In Munawar, M. \& R. E. Hecky (eds), Great Lakes of the World: Food webs, health and integrity. Backhuys, Leiden: 47-66.

Komárek, J. \& K. Anagnostidis, 1998. Cyanoprokaryota 1. Teil: Chroococcales. In Ettl, H., G. Gärtner, H. Heyning \& D. Mollenhauer (eds), Süsswasserflora von Mitteleuropa 19/1, Gustav Fisher, Jena-Stuttgart-Lübeck-Ulm: p. 548.

Komárek, J. \& K. Anagnostidis, 2005. Cyanoprokaryonta 2.Teil. Oscillatoriales. In Büdel, B., G. Gärtner, L. Krienitz \& M. Schagerl (eds), Süßwasserflora von Mitteleuropa 19/2. Elsevier, Spektrum Akad. Verlag, Munich, Germany: $759 \mathrm{pp}$.

Komárek, J. \& B. Fott, 1983. Chlorophyceae (Grünalgen), Ordnung Chlorococcales. In Huber-Pestalozzi, G. (ed.), Das Phytoplankton des Süsswassers, Die Binnengewässer 16, 7/1. Schweizerbart Verlag, Stuttgart: p. 1044.

Komárek, J., M. F. O. S. Azevedo, P. Domingos, J. Komárkova \& M. Tichy, 2001. Background of the Caruaru tragedy; a case taxonomic study of the cyanobacteria. Algological Studies 103: 9-29.

Komárek, J., J. Komárkova-Legnerová, C. L. Santana, M. T. P. Azevedo \& P. A. C. Senna, 2002. Two common Microcystis species (Chroococcales, Cyanobacteria) from tropical America, including $M$. panniformis sp. nov. Cryptogamie Algologie 23: 159-177.

Krammer, K. \& H. Lange-Bertalot, 1988. Süßwasserflora von Mittleuropa. In Ettl, H., J. Gerloff, H. Heynig \& D. Mollenhauer (eds), Bacillariopyceae, Epithemiaceae, Surirellaceae 2/2 1-596. Fischer, Stuttgart, New York.

Krammer, K. \& H. Lange-Bertalot, 1991. Süßwasserflora von Mitteleuropa. In Ettl, H., J. Gerloff, H. Heynig \& D. Mollenhauer (eds), Bacillariophyceae. 3. Teil: Centrales, Fragilariaceae, Eunotiaceae, 2/3 1-576. VEB Gustav Fischer Verlag, Jena.

Krienitz, L., A. Ballot, C. Wiegand, K. Kotut, G. A. Codd \& S. Pflugmacher, 2002. Cyanotoxin producing bloom of Anabaena flos-aquae, Anabaena discoidea and Microcystis aeruginosa (Cyanobacteria) in Nyanza Gulf of Lake Victoria, Kenya. Journal of Applied Botany 76: 179-183.

Krom, M. D., 1982. Spectrophotometric determination of ammonia: a study of a modified Bertholet reaction using salicylate and dichlorisocyanurate. Analyst 105: 305-316.

Kurmayer, R., G. Christiansen \& I. Chorus, 2003. The abundance of microcystin-producing genotypes correlates positively with colony size in Microcystis and determines its microcystin net production in Lake Wannsee. Applied and Environmental Microbiology 69: 787-795.

Lawton, L. A., C. Edwards \& G. A. Codd, 1994. Extraction and high-performance liquid chromatographic method for the determination of microcystins in raw and treated waters. Analyst 119: 1525-1530. 
Lung'ayia, H. B. O., A. M'Harzi, M. Tackx, J. Gichuki \& J. J. Symoens, 2000. Phytoplankton community structure and environment in the Kenyan waters of Lake Victoria. Freshwater Biology 43: 529-543.

Lung'ayia, H., L. Sitoki \& M. Kenyanya, 2001. The nutrient enrichment of Lake Victoria (Kenyan waters). Hydrobiologia 458: 75-82.

Müller, R. \& O. Wiedemann, 1955. Die Bestimmung des Nitrations im Wasser. Vom Wasser 22: 247-271.

Ochumba, P. B. O., 1990. Massive fish kills within the Nyanza Gulf of Lake Victoria, Kenya. Hydrobiologia 208: 93-99.

Ochumba, P. B. O. \& D. I. Kibaara, 1989. Observations on bluegreen algal blooms in the open waters of Lake Victoria, Kenya. African Journal of Ecology 27: 23-34.

Okello, W., C. Portmann, M. Erhard, K. Gademann \& R. Kurmayer, 2010a. Occurrence of microcystin-producing cyanobacteria in Ugandan freshwater habitats. Environmental Toxicology 25: 367-380.

Okello, W., V. Ostermaier, C. Portmann, K. Gademann \& R. Kurmayer, 2010b. Spatial isolation favours the divergence in microcystin net production by Microcystis in Ugandan freshwater lakes. Water Research 44: 2803-2814.

Okely, P., J. Imberger \& J. P. Antenucci, 2010. Processes affecting horizontal mixing and dispersion in Winam Gulf, Lake Victoria. Limnology and Oceanography 55: 1865-1880.

Ozawa, K., H. Fujioka, M. Muranaka, A. Yokoyama, Y. Karagami, T. Homma, K. Ishikawa, S. Tsujimura, M. Kumagai, M. F. Watanabe \& H. D. Park, 2005. Spatial distribution and temporal variation of Microcystis species composition and microcystin concentration in Lake Biwa. Environmental Toxicology 20: 270-276.

Paerl, H. W., J. Tucker \& P. T. Bland, 1983. Carotenoid enhancement and its role in maintaining blue-green algal (Microcystis aeruginosa) surface blooms. Limnology and Oceanography 28: 847-857.

Poste, A. E., R. E. Hecky \& S. L. Guildford, 2011. Evaluating microcystin exposure risk through fish consumption. Environmental Science \& Technology 45: 5806-5811.

Reynolds, C. S., 2006. The Ecology of Phytoplankton. Cambridge University Press, Cambridge: 535 pp.
Rippka, R., 1988. Isolation and purification of cyanobacteria. Methods in Enzymology 167: 3-27.

Rott, E., 1981. Some results from phytoplankton counting intercalibrations. Schweizerische Zeitschrift für Hydrologie 43: 34-62.

Salas, H. J. \& P. Martino, 1991. A simplified phosphorus trophic state model for warm-water tropical lakes. Water Research 25: $341-350$.

Sekadende, B. C., T. J. Lyimo \& R. Kurmayer, 2005. Microcystin production by cyanobacteria in the Mwanza Gulf (Lake Victoria, Tanzania). Hydrobiologia 543: 299-304.

Semyalo, R., T. Rohrlack, C. Naggawa \& G. W. Nyakairu, 2010. Microcystin concentrations in Nile Tilapia (Oreochromis niloticus) caught from Murchison Bay, Lake Victoria and Lake Mburo: Uganda. Hydrobiologia 638: 235-244.

Sitoki, L. M., 2010. Phytoplankton and eutrophication in Nyanza Gulf (with special reference to toxic cyanobacteria and planktonic diatoms). Ph.D. thesis, University of Innsbruck, Faculty of Biology, Institute of Botany: 106 pp.

Talling, J. F., 1987. The phytoplankton of Lake Victoria (East Africa). Archiv für Hydrobiologie Beiheft Ergebnisse Limnologie 25: 229-256.

Utermöhl, H., 1958. Zur Vervolkommung der quantitativen Phytoplankton-Methodik. Mitteilung Internationalen Vereinigung für theoretische und angewandte Limnologie 9: $1-38$

Verschuren, D., T. C. Johnson, H. J. Kling, D. N. Edgington, P. R. Leavitt, E. T. Brown, M. R. Talbot \& R. E. Hecky, 2002. History and timing of human impact on Lake Victoria, East Africa. Proceedings of the Royal Society of London B 269: 289-294.

Welker, M. \& H. von Döhren, 2006. Cyanobacterial peptidesnature's own combinatorial biosynthesis. FEMS Microbiology Reviews 30: 530-563.

Wetzel, R. G. \& G. E. Likens, 2000. Limnological Analyses, 3rd edn. Springer, New York: p. 429.

White, S. H., L. D. Fabbro \& L. J. Duivenvoorden, 2003. Changes in cyanoprokaryote populations, Microcystis morphology, and microcystin concentrations in Lake Elphinstone (Central Queensland, Australia). Environmental Toxicology 18: 403-412. 